\author{
Hanna FABCZAK ${ }^{1}$, MARIA Jolanta RęowiCZ ${ }^{2}$, Dorota WŁoGA ${ }^{1}$ \\ ${ }^{1}$ Pracownia Cytoszkieletu i Biologii Rzęsek \\ Zakład Biologii Komórki \\ ${ }^{2}$ Pracownia Molekularnych Podstaw Ruchów Komórkowych \\ Zakład Biochemii \\ Instytut Biologii Doświadczalnej PAN \\ Pasteura 3, 02-093 Warszawa \\ E-mail: h.fabczak@nencki.gov.pl \\ j.redowicz@nencki.gov.pl \\ d.wloga@nencki.gov.pl
}

\title{
CYTOSZKIELET I RUCH KOMÓRKI
}

Cytoszkielet, czyli obecna w każdej komórce eukariotycznej wewnattrzkomórkowa sieć włókien (polimerów) białkowych, odgrywa zasadniczą rolę w utrzymaniu kształtu komórek, dynamice błon, transporcie wewnatrzkomórkowym i pozycjonowaniu organelli, polaryzacji komórek, ich ruchu i podziałach.

Podstawę cytoszkieletu stanowią trzy rodzaje struktur: filamenty aktynowe (zwane też mikrofilamentami), filamenty pośrednie oraz mikrotubule wraz $z$ towarzyszacymi im białkami, regulujacymi nukleację polimerów, zakrywającymi (czapeczkującymi) końce polimerów, fragmentujacymi polimery, sieciujacymi filamenty, pełniacymi funkcje strukturalne, oraz białkami motorycznymi. Poszczególne elementy cytoszkieletu: filamenty aktynowe, filamenty pośrednie i mikrotubule, sa ze soba połaczone za pośrednictwem oddziałujacych $z$ nimi białek powodujac, że cytoszkielet stanowi funkcjonalna całość. Wzajemne powiąania elementów cytoszkieletu i udział w przekazywaniu bodźców płynących ze środowiska sprawia, że cytoszkielet odgrywa kluczowa rolę w prawidłowym rozwoju i funkcjonowaniu tkanek i narządów, a zatem w utrzymaniu prawidłowej homeostazy organizmu. Zaburzenia w prawidłowym funkcjonowaniu cytoszkieletu prowadza do wielu poważnych chorób (np. pęcherzowego oddzielania się naskórka, miopatii, neuropatii, ciliopatii i chorób nowotworowych).

Główne białka budujące cytoszkielet, takie jak aktyna czy a- i $\beta$-tubulina, sa zadziwiajacco dobrze zachowane w toku ewolucji we wszystkich komórkach eukariotycznych, a tworzone $z$ nich polimery maja charakter polarny, czyli posiadają różne pod względem właściwości końce: plus i minus. W odróżnieniu od aktyny i tubuliny, białka tworzace filamenty pośrednie występuja tylko u zwierząt i sa specyficzne komórkowo i tkankowo. Tym co je łączy, to, pomimo różnic w sekwencji aminokwasowej, podobna budowa II-rzędowa poszczególnych białek oraz tworzonych przez nie filamentów. W odróżnieniu od mikrofilamentów i mikrotubul, filamenty pośrednie sa apolarne $\mathrm{i}$ nie oddziałuja $z$ białkami motorycznymi.

Choć określenie "cytoszkielet” może w naturalny sposób kojarzyć się ze słowem „szkielet”, a więc czymś stabilnym i niezmiennym (jak np. układ kostny człowieka), to w rzeczywistości sieć włókien wewnątrzkomórkowych jest układem dynamicznym, w którym zachodzi zarówno wymiana podjednostek w istniejacych już polimerach, jak i lokalna lub globalna przebudowa sieci włókien (możliwa dzięki procesom polimeryzacji i depolimeryzacji poszczególnych filamentów). Taka dynamika cytoszkieletu umożliwia nie tylko wyeliminowanie uszkodzonych podjednostek lub fragmentów struktur i zastapienie ich przez jednostki prawidłowe, ale również reorganizację cytoszkieletu w odpowiedzi na różne bodźce wewnętrzne i zewnętrzne, np. w trakcie podziału komórki lub jej różnicowania oraz migracji komórek.

Nie wszystkie struktury cytoszkieletu charakteryzuja się dużą dynamika (zależy to od funkcji, jaka pełnia one w komórce). 
Obecność białek towarzyszących umożliwia oddziaływania pomiędzy polimerami tego samego typu i w efekcie tworzenie bardziej stabilnych struktur jak wiazki (np. złożone $z$ mikrofilamentów włókna naprężeniowe oraz filamenty cienkie w mięśniach) lub organella takie, jak centriole i rzęski zbudowane na bazie szkieletu mikrotubularnego.

Kolejną rzeczą, na która należy zwrócić uwagę podczas opisywania cytoszkieletu jest zróżnicowanie właściwości mikrotubul, filamentów aktynowych i filamentów pośrednich, nie tylko w poszczególnych przedziałach komórki, ale również na różnych etapach cyklu komórkowego i różnicowania. Takie zróżnicowanie jest możliwe np. dzięki wbudowywaniu w mikrotubule różnych izotypów a- i $\beta$-tubuliny, modyfikacjom potranslacyjnym tubuliny, aktyny $i$ białek budujących filamenty pośrednie, jak też dzięki licznym białkom oddziałujacym $z$ mikrotubulami i mikrofilamentami. Różnice we właściwościach poszczególnych elementów cytoszkieletu przekładaja się $z$ kolei na pełnione przez nie funkcje.

Inspiracja do powstania niniejszego numeru KOSMOSU jest przypadajace w 2018 r. stulecie istnienia Instytutu Biologii Doświadczalnej im. Marcelego Nenckiego Polskiej Akademii Nauk, oraz upamiętnienie wieloletnich badań nad cytoszkieletem i ruchem komórek oraz skurczem mięśni od lat prowadzonych w Instytucie. Dlatego na niniejszy zeszyt KOSMOSU składaja się artykuły przybliżające czytelnikom tę tematykę badań.
Mamy świadomość, że zebrane tutaj artykuły nie poruszaja wszystkich zagadnień zwiazanych $z$ ta niezmiernie szeroka tematyka, co wynika ze specyfiki prowadzonych w Instytucie badań. I tak np. zabrakło artykułów o filamentach pośrednich. Mamy jednak nadzieję, że te, które udało się nam przedstawić przybliża Czytelnikom kierunki badań nad intrygujacymi nas zagadnieniami zwiazanymi $z$ cytoszkieletem i ruchem. Autorzy zamieszczonych artykułów byli lub sa związani $z$ Instytutem Nenckiego i w znaczącej większości są wychowankami Instytutu.

Przygotowanie tego zeszytu KOSMOSU zbiega się również z 50-leciem odkrycia filamentów pośrednich przez Howarda Holtzera i współpracowników oraz obchodzonym w zeszłym roku 50-leciem odkrycia tubuliny przez Gary'ego Borisy i Eda Taylora, a także 75-leciem badań Alberta Szent-Györgyi i jego współpracowników, prowadzących do odkrycia aktyny. Ponadto, w przyszłym roku minie 60 lat od przedstawienia przez Hugh E. Huxleya i Jean Hanson teorii ślizgowej skurczu mięśni. Więcej kluczowych odkryć („kamieni milowych”) w badaniach nad cytoszkieletem można znaleźć pod adresem www.nature.com/milestones/cytoskeleton.

Wszyscy zaangażowani w przygotowanie niniejszego numeru KOSMOSU pragna serdecznie podziękować Dyrekcji Instytutu Nenckiego za pomoc finansowa w wydaniu tego wyjatkowego dla nas zeszytu.

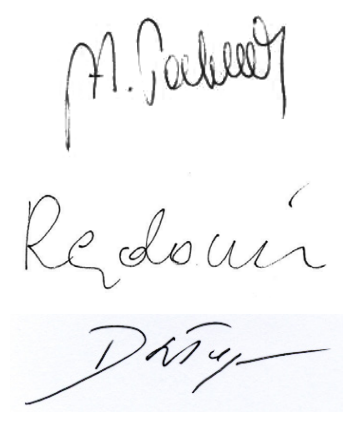

